\title{
THE DISCURSIVE CONSTRUCTION OF GENDER, ETHNICITY AND THE WORKPLACE IN SECOND GENERATION IMMIGRANTS' NARRATIVES
}

\author{
THE CASE OF MOROCCAN WOMEN IN BELGIUM
}

\author{
Dorien Van De Mieroop
}

\begin{abstract}
This article examines the professional identity construction of three young $2^{\text {nd }}$ generation immigrant women of Moroccan descent who have university degrees and high-skilled jobs. More specifically, I focus on how they construct this professional identity in relation to their gender and ethnicity. The data consist of interviews in which the interviewer explicitly probes for the relation between these topics. Interestingly, all the interviewees construct their professional identities in relatively similar ways. Furthermore, they resist the interviewer's projections of ethno-professional identities and replace these by professional identities, thus making ethnicity irrelevant for the discussion. Finally, when discussing gendered identities, they all orient to the Western hegemonic model of the struggle in finding a work-life balance. As such, these interviewees bracket ethnicity which may be related to the role of the interviewer, interviews as a genre, and the interviewees' orientation to societal norms.
\end{abstract}

Keywords: Professional identity; Gender; Ethnicity; $2^{\text {nd }}$ generation immigrants; Interviews; Narrative; Moroccan women.

\section{Introduction}

Linguists typically regard identities from a social constructionist perspective, and thus "we create rather than discover ourselves and other people" (Burr 1995: 28-29). This view of identity as "a process", rather than "a product" has been described as "the most general perspective" on identity (De Fina et al. 2006: 2). It thus remains essential to look at identity claims "as 'acts' through which people create new definitions of who they are" (De Fina et al. 2006: 3). However, "situated displays of identity relate in many ways to the more general identities that are built by social groups" (De Fina 2006: 354). This draws on Tajfel's notion of social identity, namely that "an individual's selfconcept [...] derives from his knowledge of his membership in a social group (or groups) together with the value and emotional significance attached to that membership" (Tajfel 1981: 255). However, in order to gain a thorough insight into identity, it is important to focus on the locally occasioned nature of identity construction and to analyze how these "shared categories and beliefs about identity become the 
object of resistance, alternative formulations and renegotiation" (De Fina 2006: 355). Furthermore, our current societies are characterized by "social processes (such) as globalization and massive migrations" (De Fina 2006: 351) and this has led to increased contact with "the other". This challenges a person's group memberships - however fluid this concept already was -, unsettles our senses of self and invites us to look at identity "from a relational perspective as involving as much what we are not as what we are" (Baynham 2006: 394-395).

This article focuses on interviews with young women who were born and raised in Belgium, but whose parents were Moroccan immigrants in Belgium. In general, this group of people is referred to as "second generation immigrants". This term, however, is fairly problematic and even contradictory, since it refers to individuals who did not migrate themselves. Alternative terms are "people of foreign descent", "people with a different socio-cultural background who are related to a different country of origin, regardless of their current nationality" (Eggerickx et al. 1999: 57), or "bicultural citizens", as was recently suggested in the Netherlands (De Volkskrant 2010) ${ }^{1}$. The latter term already indicates the problematic nature of the group memberships of these second generation immigrants. This is because the term highlights both the association with their place of birth (i.e. Belgium) and their ethnic country of origin (i.e. Morocco) to which their older family members often still relate quite strongly (cf. Paoletti and Cavallaro Johnson 2007). Furthermore, in spite of having Belgium as their place of birth, they are often still regarded in Belgian society as a marked group, which is labeled depending on their country of origin (i.e. Moroccans).

Furthermore, this complex ethno-cultural membership is not only constructed and negotiated in relation to other ethnic and social groups (e.g. De Fina 2006), but it also comes into contact with other potential memberships. First of all, institutional group membership is important, since this typically entails the construction of a specific kind of professional identity which is potentially guided by workplace norms and expectations (cf. Schnurr 2009). Such professional identities may interfere with other for example, ethnic - group memberships and this may lead individuals to renegotiate the construction of their identities. Secondly, the interviewees in this study are all women. The discursive enactment of the position of women in the workplace has been widely studied (for an overview, see Mullany 2009 and Wagner \& Wodak 2006). Regarding identities, women in managerial positions have been observed to face a complex task in constructing legitimate professional identities while breaking - or trying to break - through the glass ceiling against the background of dominant discourses of femininity and masculinity (Mullany 2006: 167-169). Since the vast majority of research in the field is devoted to 'white middle-class women in positions of corporate power' (Mullany 2009: 221), this study aims to contribute to completing the picture of women in the workplace in a globalized, multi-cultural society. In particular, the analyses zoom in on identity construction at the crossroads of their group memberships based on ethnicity, gender and profession.

Interviews were chosen as data since they provide privileged access to identities "because the purpose of narrating is precisely the creation of an autonomous, unique

1 This article uses both the terms 'people of foreign descent' and 'second generation immigrants', simply because they are in common use. While the former is used here as an umbrella term covering many different types of allochthonous people, the latter refers specifically to the particular subgroup of 'immigrants' that this article focuses on. 
self in discourse" (Johnstone 1996: 56). Of course, as has been discussed by for instance Georgakopoulou (2006), the identities that are constructed in such interview data are often more stable and less negotiated than identities that are talked into being in naturally occurring data. However, the role of the interviewer in co-constructing the narrative (cf. De Fina 2011; Holstein \& Gubrium 2003) should not be underestimated. This is particularly the case in these interviews, since the paper addresses both the way in which the interviewees construct their identities and the way in which they deal with categorizations that are projected upon them by the interviewer.

More specifically, the data ${ }^{2}$ consist of three interviews that took place in 2009. These interviews were chosen because of the similarities between the interviewees: They are all women of Moroccan descent who have a Belgian university degree, they are all in their late twenties to early thirties, and they have a fairly high ranking job related to their degree. They do not yet have children and only one interviewee (interviewee 3) is married. None of them wear the headscarf, which is often a reason for discrimination in Belgium (cf. below). They were all born and raised in the city of Antwerp and they are employed in quite different professional domains, as the following overview demonstrates:

- The first interviewee is 33 years old. She has a university degree in French and Spanish and is currently a secondary school teacher of French. She teaches children between 15 and 18 years old.

- The second interviewee is 31 years old. She has a university degree in International Politics. After she obtained this degree, she worked abroad for a couple of years. When she returned to Belgium, she did a few internships in media companies. She is currently working as a journalist for a news website.

- The third interviewee is 26 years old. She has a university degree in Communication Science and is still studying to obtain a Masters in Comparative and European Politics. She is the managing partner of a consultancy firm that is involved in engineering diversity and recruitment. When the interviewee started her studies, she was already married and she was working almost full-time, which is rather exceptional for students in Belgium.

These interviewees interacted with a 21 year old female interviewer who was of autochthonous descent. Due to her friendly relations with young people of foreign descent who brought her into contact with the interviewees, she was quite familiar with the topic of the interviews. These were conducted as part of a project concerned with young allochthonous women's lives in general and their views on several aspects of society.

Before going into the analyses, and in order to provide some background information on the interviewees' professional circumstances, I briefly discuss the socioeconomic situation of second generation immigrants on the Belgian labour market.

${ }^{2}$ I am largely indebted to Alexandra Van Brempt who collected the interviews and made the initial transcription of the data. 


\section{Education and employment of second generation immigrants in Belgium}

A recent OECD study focusing on the education and employment of second generation immigrants in European OECD-member states indicated that second generation immigrants typically have a lower level of educational attainment than the children of autochthonous people (OECD 2010: 5). This gap is particularly large for people of Turkish and Moroccan descent and this is particularly so for Belgium (OECD 2010: 17). Moreover, Belgium, together with the Netherlands, also has a similarly bad record regarding employment. This is because, in these countries, second generation immigrants have employment rates that are more than $20 \%$ lower than those of the autochthonous people (OECD 2010: 20). A recent investigation into job selection procedures by Andriessen et al. (2010) revealed that the gap in employment rates can only be partially accounted for in terms of educational attainment and that, even within samples where educational levels are similar, differences in employment rates still remain. Given these results, it is not surprising that more than $25 \%$ of second generation immigrants in Belgium are unemployed and that they are underrepresented in highlyskilled occupations (OECD 2010: 24-25).

Further, women in the age range 20-29 could be seen to face a "double disadvantage" because they are often (already) married and have children (OECD 2010: 29). Yet evidence from the Netherlands (Andriessen et al. 2010) indicates that, relatively speaking, and somewhat paradoxically, gender can be an advantage for second generation immigrant women on the job market because allochthonous men are more often the victim of discrimination than women. And, as Andriessen et al. (2010) also point out, second generation immigrants with a university degree are not so often discriminated against when searching for jobs, especially when compared to their peers with a lower degree or no degree at all. Thus highly educated second (or third) generation immigrant women who do not have a young family, generally have a better chance on the job market than men of allochthonous descent.

Yet despite these two relative 'advantages', Moroccan women also face a number of problems in the workplace. One of these problems is related to the Islamic tradition of wearing headscarves which marks them out as recognizably 'different'. This tradition is adhered to by a great number of second (and third) generation women in Belgium. As such, this group is visibly marked and this has led to some highly mediatized debates in Belgium. For example, in March 2011 a woman lost her job because she wore a headscarf when she was working at a shop (Lesaffer 2011) and in November 2006 city employees in Antwerp were forbidden to wear the headscarf (Verschelden \& De Lobel 2006). Furthermore, the presence of headscarves in Belgian secondary schools, especially in the public educational system (Gemeenschaps- onderwijs), is also a heavily debated issue (De Standaard 2009). Whilst the issue of wearing the headscarf is extremely visible and iconic, it is also true that second generation immigrant women who do not wear the headscarf have to deal with reactions regarding their descent as well, both from their colleagues and their clients.

In conclusion, it can be said that professional and educational success for second (or third) generation immigrants is rare and this observation is especially true for women. However, the few second (or third) generation immigrant women who are highly educated do have a fairly good chance on the job market. Unfortunately though, they are the exception rather than the rule and, when wearing the headscarf, they often 
face significant criticism in the Belgian workplace. Since this article focuses on the narratives of women who do not wear the headscarf, they are part of the group that is most successful on the Belgian job market in comparison with other second generation immigrants.

\section{Analyses}

In this section, I discuss the way the interviewee's ethnic, gendered and professional memberships are negotiated by the interviewees and the interviewer, who has an active role in the identity negotiations that occur in these data (see e.g. De Fina 2009; Van De Mieroop 2011). This means that in the analyses, I not only focus on elements that are situated on a lexical and a textual pragmatic level (cf. De Fina 2003), but also on an interactional level, which refers to "the devices and strategies used by narrators to index their stances and attitudes both towards their own texts and other interlocutors" (De Fina 2003: 23). Instead of discussing these levels separately though, I present the findings on these three levels of analysis in an integrated way. As such, I intend to provide a holistic insight into the identity constructions and negotiations that are present in this dataset.

I first discuss each interview separately so that the reader gains an insight into the identities that were interactively constructed between the interviewer and each individual interviewee. Given this article's focus on ethnic, gendered and professional identities, I selected the most relevant fragments from the analyses of the entire interviews. For this selection, I also made sure that each interview's analyses are presented in a comparable way so that a balanced view on the entire dataset is achieved. So for each interview, I analyze fragments regarding (1) the 'balancing act' between a job and a family that women are often expected to perform, and (2) reactions of the interviewees' colleagues to their ethnic backgrounds. As such, I scrutinize the intersections between the three group memberships that are relevant here. After dealing with these interviews consecutively, in the final sections of this article I go into a more general discussion of the findings.

\subsection{Interview 1}

In the first interview, a secondary school teacher is interviewed. This interviewee strongly identifies with her institution. Throughout the interview, she consistently uses an institutional we-form to refer to the school where she works, and she also refers to the umbrella term for the sector she is in, namely 'education'. Also when the topic shifts to the discussion of the work-life balance, the interviewee continues to foreground the construction of her professional identity. This can be seen in the following fragment, in which the interviewer quite abruptly initiates the topic of combining a job with a family. She introduced this topic with a general statement about women going back to work quickly after having given birth, and then, in lines 366-367, she shifts to a personal footing and addresses the interviewee directly: 
(1)

\begin{tabular}{|c|c|c|}
\hline $\begin{array}{l}366 \\
367\end{array}$ & $I R$ & $\begin{array}{l}\text { Maar hoe zoudt ge in de toekomst uw carrière } \\
\text { en ww oezin willen combineren? }\end{array}$ \\
\hline 368 & $I E$ & Ja in 't onderwijs is da geen probleem natuurlijk he. \\
\hline 369 & & Wij moeten:: wij zijn 20 uur op school en wij hebben altijd gedaan om, \\
\hline 370 & & in het ergste geval, half 4. En meestal twee keer om 12 uur, 1 uur. \\
\hline 371 & & Dus ik denk dat da in mijn sector perfect (.) combineerbaar is. \\
\hline & IR & $\begin{array}{l}\text { But in the future, how would you want to combine your } \\
\text { career and your family? }\end{array}$ \\
\hline & IE & Yes, in the education((al sector $))$, that is no problem of course hey. \\
\hline & & We have to:: we are 20 hours at school and we are always finished at, \\
\hline & & $\begin{array}{l}\text { in the worst case, half past } 3 \text {. And usually two times at } 12 \text { o'clock, } 1 \\
\text { o'clock. }\end{array}$ \\
\hline & & So I think that that can be perfectly (.) combined in my sector. ${ }^{3}$ \\
\hline
\end{tabular}

The interviewee starts her answer with an impersonally formulated, general statement about the educational sector. In line 369, she switches to the institutional we-form, which in this case refers to all the secondary school teachers in Belgium. She presents this sector in a very positive way, as is shown by the reformulation that corrects the modal verb of obligation in line 369 (Wij moeten:: wij zijn, 'we have to:: we are') and by the construction of a contrast between the stressed formulation 'worst case' (ergste geval, line 370) and the content (she always finishes at half past 3). This is further underlined by the use of the booster 'perfectly' (perfect, line 371) in the evaluative topic-closing sentence (line 371). This sentence is again voiced from a personal perspective, as is shown by the explicit opinion marker 'I think' ( $i k$ denk) (Chilton 2004: 97) and by the use of the prosodically marked first person possessive pronoun

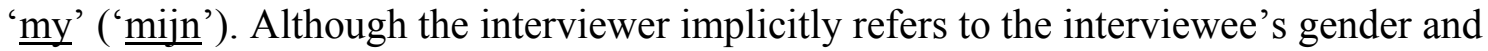
her potential role as a mother, this role is not particularly referred to in the answer. Instead, the interviewee positions herself strongly within the professional in-group of teachers and orients to the Western model of combining a family with a professional career.

As mentioned above, the interviewee also uses the institutional we-form to refer to the school where she is working. Interestingly, she not only contrasts her own professional teacher identity with that of her students, but more specifically, she contrasts it with students of foreign descent. In the fragment below, she uses the cover term 'foreigners' (vreemdelingen) for this group of students and she self-initiates this topic in the middle of a turn that focuses on the lack of Moroccan students at the university. This turn is elicited by the interviewer's follow-up question (line 125) which probes for an explanation of the interviewee's observation that she was the only Moroccan student in her department of the university when she graduated (line 125).

$$
125 \text { IR Ja. En hoe komt da denkt ge? Dat er zo weinig interesse voor is? }
$$

${ }^{3}$ The fragments were transcribed using the Jefferson transcription system as explained in Antaki (2002). The translation is as literal as possible and thus odd sentences in English are based on strange formulations in Dutch. 


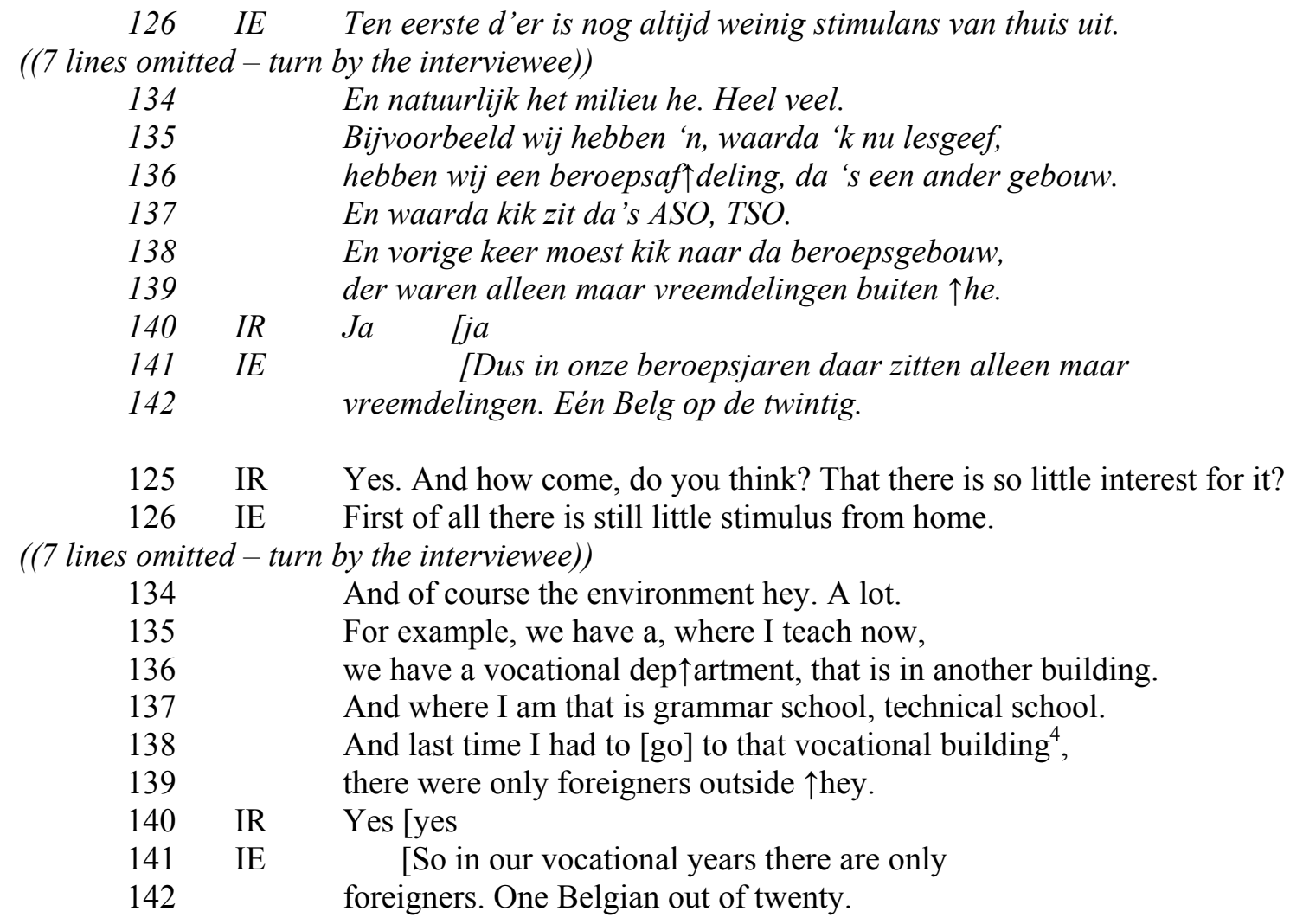

In this fragment, the interviewer is referring to the interviewee's former 'professional' identity, namely that of a student. The interviewee starts her answer from a general, impersonal perspective (d'er is, 'there is', line 126) which is maintained throughout the first nine lines of the fragment. But in the middle of her turn, the interviewee provides an anecdote to back her general claim. She clearly marks this story by introducing it as an example (bijvoorbeeld, 'for example', line 135) and by switching to the institutional we-form (line 135). As such, she again constructs her professional identity as a teacher. In spite of its brevity, this story reflects some of the typical story aspects as outlined by Labov and Waletzky (1967) and it starts with quite an extensive orientation in comparison with the rest of the story. This orientation is not only spatial, but it also situates the interviewee as a teacher of the higher - more prestigious - levels. As such, she both distances herself from the students by her role as a teacher and she adds prestige to her teacher identity. Interestingly, while she uses the official abbreviations for the levels she is teaching (ASO, TSO), she consistently uses the more informal Flemish indication for the lowest level (beroeps, 'vocational' in lines 136, 138 and 141). This further underlines the distinction between the two highest levels on the one hand, and the lowest level on the other hand. The story then moves into the complicating action, which is limited to two narrative clauses describing the protagonist's action (line 138) and observation (line 139). The latter is formulated from an impersonal perspective

${ }^{4}$ The levels of secondary education that are mentioned here are ASO, TSO and BSO. These relate to each other in the following way: (1) the highest level is called ASO (general secondary school) which is the most academically oriented level and it prepares pupils for university education; (2) the intermediate level is called TSO (technical secondary school) which provides a basis for continuing at a professional bachelor level; (3) the lowest level is called BSO (vocational secondary school) which is intended to teach vocational skills. 
again (der waren, 'there were') which constructs "out-there-ness" (Edwards \& Potter 1992: 105). This is further enforced by the use of numbers in the closing sentence (line 142), which has an objectifying effect (cf. Potter, Wetherell \& Chitty 1991). Finally, the use of the word 'foreigners' constructs these immigrant pupils as the out-group, especially since they are contrasted with the 'Belgians' (line 142). Thus the interviewee not only replaces the interviewer's projection of a former student identity by her current professional identity - as shown by the consistent use of the institutional we-form (line 135,136 and 141) - but, by self-initiating this topic of the immigrant pupils, she also resists any categorization of herself based on ethnicity.

During a lengthy discussion of the interviewee's experience with racism, the interviewer explicitly probes for positive reactions to the interviewee's ethnic background from professional antagonists (students, colleagues). In this fragment, the interviewee takes a fairly critical stance towards the marked character of the others' positive evaluations.

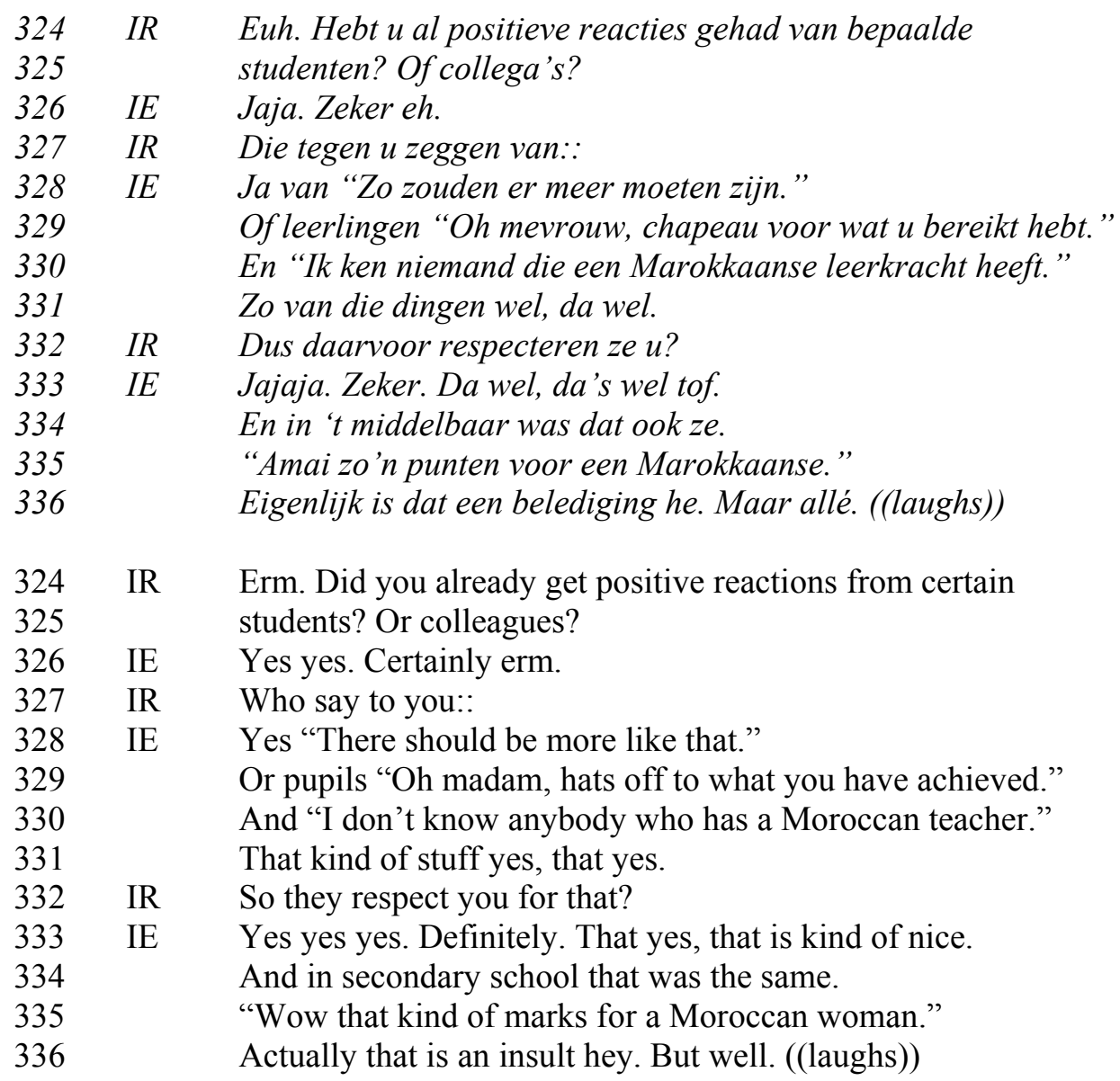

The interviewee initially provides a brief affirmative response, which is boosted (zeker, 'certainly', line 326). The interviewer then prompts her to tell an anecdote by voicing the introductory phrase of a direct quote, of which the final sound is extended (line 327). The interviewee mirrors this final word (van, line 238, not translated in English) and fills in some direct quotes as examples of reactions. She starts by a general quote 
which vaguely refers to her ethnic origins (zo, 'like that', line 328). Then she moves to a more personally formulated compliment (cf. direct address oh mevrouw, 'oh madam', line 329). Finally, in the third quote, she explicitly links her ethnic origin to her professional identity (Marokkaanse leerkracht, 'Moroccan teacher', line 330). She then generally concludes the topic. After yet another prompt by the interviewer (line 332), she initially gives a boosted affirmative response (cf. the repetition of the affirmative particle $j a$, 'yes' three times and the booster zeker, 'definitely' in line 333). But then she replaces the booster with a hedged positive evaluation (wel tof, 'kind of nice' in line 333). Furthermore, she self-initiates an extension of her answer in which she refers to her time as a secondary school pupil. After another general statement (line 334), she again uses a direct quote to voice the positive evaluation she received as a pupil. In this quote (line 335), the categorization relates both to ethnicity and gender. This quote is then immediately evaluated in a critical way (een belediging, 'an insult', line 336), but this negative evaluation is also downgraded by: The initial hedge eigenlijk ('actually', line 336); the closing contrastive hedge maar allé ('but well', line 336); and her laughter that closes the topic.

So in this fragment, the interviewee shifts her evaluations of the reactions to the link between her ethnicity (and implicitly also her gender (line 335)) and her professional success (as a teacher, but also as a pupil). She is on the one hand positive, but on the other hand, she is critical of the marked character others assign to this association between her professional and her ethnic categorization.

During the development of this discussion of racist talk, a further dimension of such reactions in a professional context is touched upon, namely the evaluation of the interviewee's ethnicity, gender and profession by pupils of her own ethnic in-group. Since the initial question is quite generally formulated (lines 248-249), this specific ethnic dimension of the topic is actually self-initiated by the interviewee.

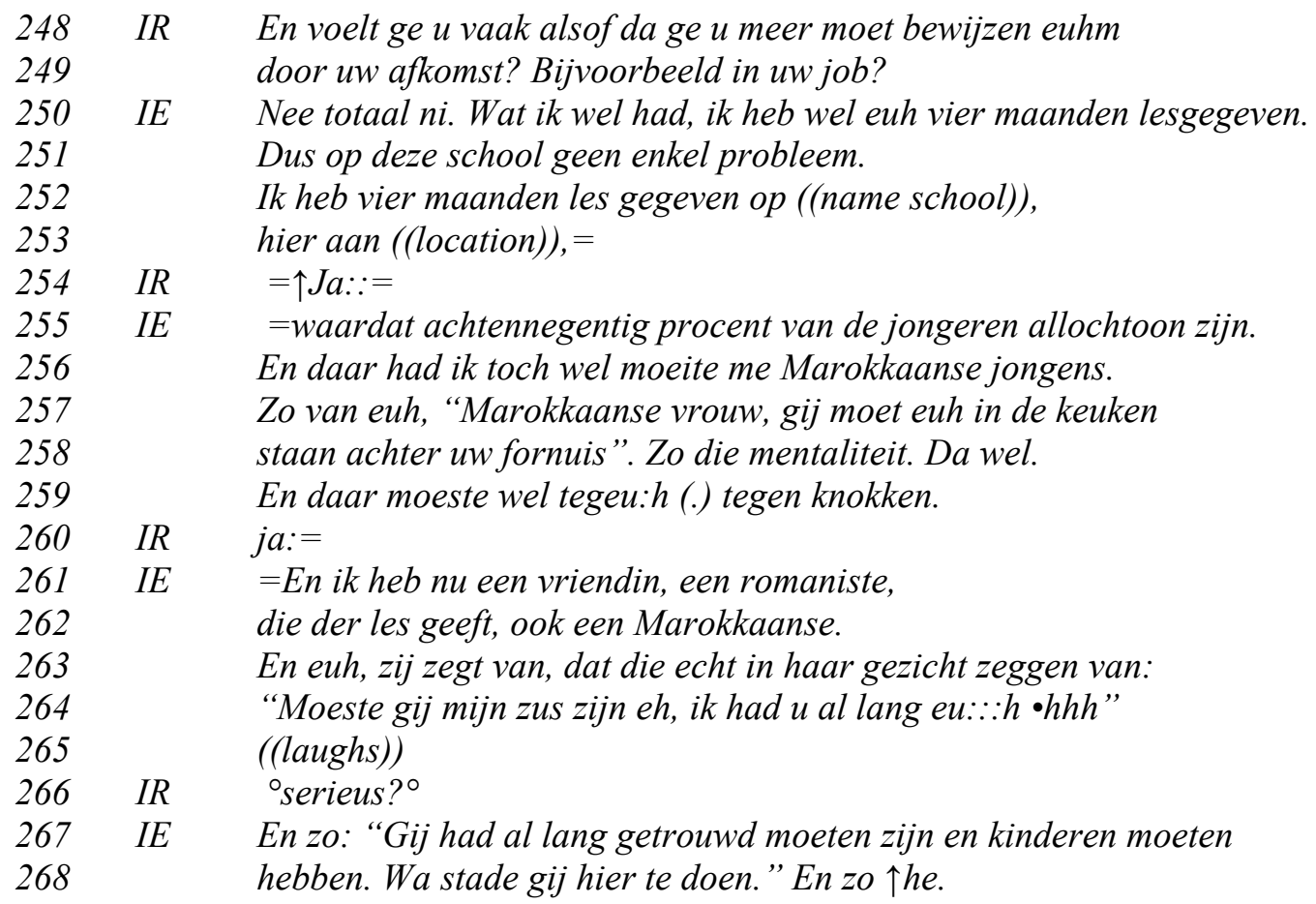




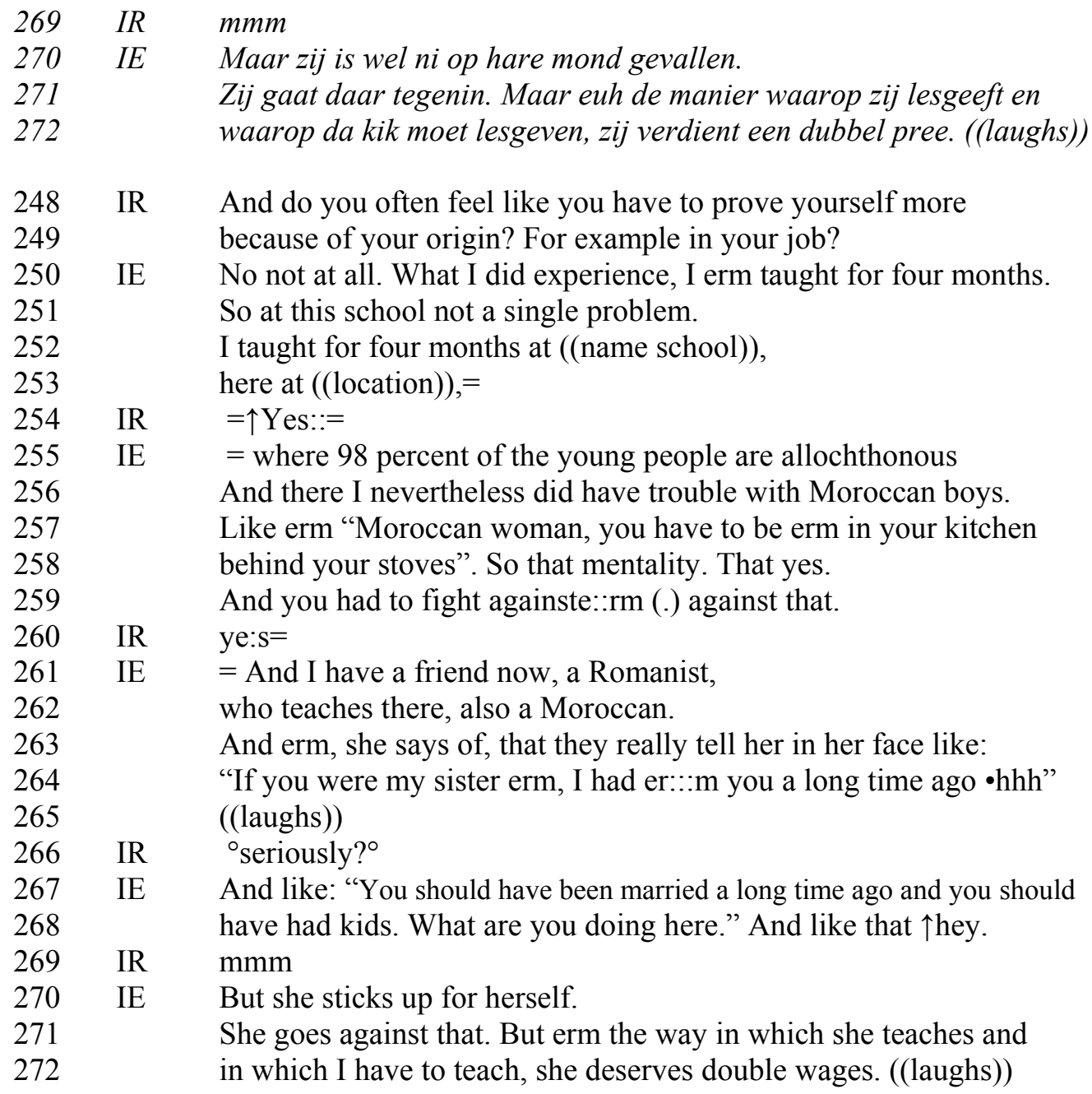

In this fragment, the interviewer probes for instances in which the interviewee's ethnicity has interfered with her professional identity. Initially, she responds negatively (line 250), but then she shifts the time frame to the past (line 250). She makes this shift more explicit by also stressing the change in location: First, she stresses the lack of problems at her current school (line 251), and then moves both time and place to another school. The name and location of this school are explicitly formulated (lines 252-253) and it is immediately qualified as a school with an extremely high population of people of foreign descent (line 255). As such, the interviewee foregrounds ethnicity as a relevant element in this story in a way that was not initiated by the interviewer, whose question was oriented solely to the interviewee's ethnicity and not to that of the pupils. She then produces the abstract of the story (line 256), in which the contrastive adverbial adjunct toch ('nevertheless') and the affirmative adverbial adjunct wel (translated as 'did (have)') correct the initial negative answer (line 250). Furthermore, this formulation also implicitly stresses the contradiction because of the fact that she is referring to antagonists that belong to her own ethnic in-group.

Returning to line 257, through three instances of reported speech, the interviewee voices her former pupils' allegations of her professional identity clashing with her ethno-gendered identity. In these direct quotes, her ethno-gendered identity is immediately made relevant through the pupil's other-categorization of the interviewee as 'Moroccan woman' (line 257), which is formulated here as a direct address. So even 
in spite of the fact that these pupils belong to the same ethnic in-group, this form of address clearly emphasizes the relevance of both gender and ethnicity. In the reported speech, a number of discriminating evaluations of the interviewee and of her friend are voiced. This friend is categorized as similar to the interviewee both professionally (cf. the reference to her diploma, line 261), ethnically (line 262) and regarding gender (vriendin in Dutch only refers to a female friend, line 261). The negative evaluations in the direct quotes refer to the Islamic hegemonic model of the division of family roles in which the woman is supposed to cook (lines 257-258), be married and have kids (lines 267-268). Also, the quote in line 264 suggests that deviant behavior is not tolerated from women and that such behaviour is sanctioned by the men within the family structure. These instances of reported speech are formulated in a normative way, as the use of modal verbs of obligation (lines 257 and 267-268) clearly indicates. Furthermore, they are also performed in a marked way. Especially the second quote (line 264) has a marked intonation, which together with the long, audible in-breath at the end adds to the dramatic nature of her words. This is immediately downplayed again by the interviewee's laughter, but it still elicits surprise from the interviewer (line 266).

Finally, the topic closure foregrounds both the interviewee's and her friend's professional identities as teachers, rather than their gendered or ethnic identities. So, in spite of these other-categorizations that stress the latter identities, the interviewee focuses solely on the fact that it is 'part of the job'. The fact that, even after discussions in which other aspects of identity come into play, the interviewee first and foremost constructs her identity as a professional is a general tendency throughout this interview.

\subsection{Interview 2}

This interview consists of an interaction with a journalist. As in the previous interview, this interviewee also immediately puts herself in the institutional in-group by consistently using an institutional we-form when she discusses her current job (e.g. lines 11-17: 'we bring news from social movements, (...) a website on which we put news, (...) that news is not only put on there by us, but we also train people to make news.'). This clearly demonstrates her alignment with this professional group.

Halfway through the interview, the interviewer introduces the topic of the worklife balance between family and career. This is inserted by means of an abrupt change in topic that is introduced by a general statement of the interviewer. This is very similar to the transition to this topic in the first interview (lines 348-349: 'Nowadays, women choose to start working again as soon as possible after giving birth'). She then shifts to a personally formulated question (line 350), in which the interviewee's gendered identity is topically foregrounded, but no reference to her ethnicity is made.

$\begin{array}{lll}350 & \text { IR } & \text { Hoe zoude zelf uw gezin en uw carrière combineren? } \\ 351 & \text { IE } & \text { Ik heb momenteel zelf geen kinderen. ((laughs)) } \\ 352 & & \text { Maar da's echt heel moeilijk om een gezin en uw carrière } \\ 353 & & \text { te combineren. Ik zie dat ook bij mensen in mijn omgeving. } \\ 354 & & \text { Zeker beroepen als journalistiek of zo van die flexibele jobs. } \\ 355 & & \text { Da kunt ge vergeten als ge kinderen hebt he. }\end{array}$




\begin{tabular}{|c|c|c|}
\hline 356 & & Als ge een vrouw zijt is da echt moeilijk. Allé ge moet \\
\hline 357 & & al chance hebben da ge een goei stabiele relatie hebt. \\
\hline 358 & & Da ge samen me uw man kinderen kunt opvoeden, \\
\hline 359 & & da ge een beetje de taken kunt verdelen. \\
\hline 360 & & Maar heel vaak blijven vrouwen achter met hun kinderen. \\
\hline 361 & & En die moeten het alleen zien te rooien. \\
\hline 350 & IR & How would you yourself combine your family and your career? \\
\hline & IE & I don't have any children myself at the moment. ((laughs)) \\
\hline & & But that is really very difficult to combine a family and your \\
\hline & & career. I also see that with people in my environment. \\
\hline & & Especially professions like journalism or those flexible jobs. \\
\hline & & You can forget about that if you have children hey. \\
\hline & & If you are a woman that is really difficult. Well, you have to \\
\hline & & already have the luck that you have a good, stable relationship. \\
\hline & & That you can raise children together with your husband, \\
\hline & & that you can divide the tasks a bit. \\
\hline & & But very often women stay behind with their children. \\
\hline & & And they have to try ${ }^{5}$ to manage it by themselves. \\
\hline
\end{tabular}

The interviewer's question does not refer to the interviewee's ethnicity in any way and this is perfectly mirrored in the interviewee's response. The answer reflects the model of Western, emancipated women who have a hard time handling both their professional and family life. Marking her personal non-involvement in the topic, the interviewee starts her response on a personal footing (line 351). Then she shifts to an impersonal perspective in which she takes on the role of a non-involved witness who observes what goes on in her 'environment' (line 353). In the following line, this 'environment' is framed as her professional context which thus demonstrates the interviewee's orientation to the professional in-group.

From line 355 onwards, the interviewee implicitly constructs an in-group with the interviewer that is based on their collective identity of women. As such, she foregrounds gender and brackets all the (ethno-cultural or professional) differences between them. She does this by shifting footing and using the Flemish, informal second person ge system. This widens the scope of her words in the sense that it "also involves the addressee, the interviewer, in the situation, thereby implying that in the same circumstances he or she too would live and behave similarly" (Timor and Landau 1998: 368). From this perspective, she describes the difficulties of working mothers in contemporary Western societies.

In line 360, the interviewee shifts back to the observer's role that she initiated in line 353 and she vaguely talks about women who 'stay behind' and have to 'manage it by themselves'. This could refer to divorced ${ }^{6}$ and/or single mothers or to mothers whose husbands do not help them manage their families and their jobs. In the entire response,

\footnotetext{
${ }^{5}$ In Dutch, the verb zien ('to see') is used, which can be translated as 'to try' but also as 'to be able' in this context.

${ }^{6}$ When interpreting this sentence as a reference to a divorce, one could say that the interviewee implicitly disaligns with the Islamic culture in which divorces are highly problematic. However, lawyers observe that it is increasingly common for second and third generation immigrants to get a divorce in Belgium (De Standaard 2005). This societal fact together with the vague formulation indicates that this statement should not be read as a disalignment with Islamic culture, but rather as an alignment with Western working women in general in which the element of ethnicity is not made relevant.
} 
the interviewee refers to women in general, thus leaving ethnicity aside and aligning with either the professional in-group or the interviewer. As such she orients to the Western hegemonic model of working women.

Only when being asked explicitly about the reactions of her colleagues to her ethnic origin (line 299: 'And did you already get certain reactions at your job about your origin?'), does the interviewee go into this topic. She does so first by referring to racist remarks of the people she has to interview as a journalist (lines 300-312). When she finishes this story, the interviewer questions her specifically about her colleagues (line 313). The interviewee then starts telling a story about one of her previous jobs:

(6)

$\begin{array}{lll}313 & \text { IR } & \text { En uw collega's en zo? } \\ 314 & \text { IE } & \text { Allé van, euh, bedoelde van houding? } \\ 315 & & \text { Bij ((name company)) was da helemaal anders als nu. } \\ 316 & & \text { Bij ((name company)) is er een heel andere sfeer he. } \\ 317 & \text { Ook zo van- } \\ 318 & \text { (1.8) } \\ 319 & \text { Ik kwam daar binnen en da was echt zo van ja, } \\ 320 & \text { "Ze hebben hier allochtonen binnengehaald", wete? } \\ 321 & \text { Die denken dat ik van een getto kom en } \\ 322 & \text { dat ik geen Nederlands spreek en zo. } \\ 323 & \text { "Ah amai, maar ge spreekt Nederlands? " } \\ 324 & \text { "Ah maar ge ziet er toch ni uit als ne- een Marokkaanse?" } \\ 325 & \text { (1.4) } \\ 326 & \text { "Ik ben journalist. Van welke planeet komen jullie?" } \\ 313 & \text { IR } & \text { And your colleagues and all? } \\ 314 & \text { IE } & \text { Well regarding, erm, you mean regarding attitude? } \\ 315 & \text { With ((name company)) that was totally different from now. } \\ 316 & \text { With ((name company)) there is a totally different atmosphere hey. } \\ 317 & \text { Also of- } \\ 318 & \text { (1.8) } \\ 319 & \text { I walked in and that was really of yes, } \\ 320 & \text { "They have brought in foreigners here", you know? } \\ 321 & \text { They think that I come from a ghetto and } \\ 322 & \text { that I don't speak Dutch and so on. } \\ 323 & \text { "Ah, wow, but you speak Dutch? " } \\ 324 & \text { "Ah but you don't look like a- a Moroccan woman?" } \\ 325 & \text { (1.4) } \\ 326 & \text { "I am a journalist. Which planet are you from?" }\end{array}$

In this fragment, the interviewee refers to a very well known company in Belgium where she used to work. She introduces the story with a general abstract (line 315-316) and then, after a false start (line 317 ) and a pause (line 318), she immediately moves into the complicating action of the story. This complicating action consists of the reenactment of a constructed dialogue. This is a typical performance device that generates audience involvement in the storyworld (Tannen 1989) and identification with the protagonists (De Fina 2006: 372). In this constructed dialogue, a clear us-them opposition is created between the story characters, namely between the employees of the company (die, 'they', line 321) and the interviewee ( $i k$, 'I', lines 321-322). The 
latter is categorized on the basis of her ethnicity, as the quotes indicate (allochtonen, 'foreigners' (line 320) and een Marokkaanse, 'a Moroccan woman' (line 324)). As Leudar et al. (2004) illustrate, this us-them categorization typically entails certain stereotypical characteristics, and these are also formulated here by the narrator. The first two characteristics, namely living conditions (ghetto, line 321) and language skills (Dutch, line 322) are presented as the thoughts of the autochthonous employees (line 321). She then counters these thoughts by voicing the antagonists' direct quotes that refute some of these stereotypical features, namely the interviewee's good command of Dutch (line 323) and her un-Moroccan looks (line 324). By framing these counterarguments as quotes from the antagonists, she gives them an objective character. Furthermore, these quotes are introduced by: Markers of contrast (maar, 'but', line 324); markers of surprise ('ah', lines 323 and 324 and 'wow', line 323); and rising intonation (lines 323 and 324). As such, the interviewee underlines the marked nature of her looks and language skills for a member of the ethnic out-group, as perceived by her autochthonous colleagues. Interestingly, in line 324, the interviewee self-corrects the indefinite article. In the original, she first said ne and then corrects to een (both translated as ' $a$ '): The former is the indefinite article for masculine words in Flemish dialect, while the latter is for feminine words. This self-repair illustrates the fact that although gender is not specifically highlighted here, the interviewee implicitly signals it by a self-correction that contains a female categorization of nationality (een Marokkaanse, 'a Moroccan woman').

This could have been the introduction of gender related categorizations, but instead, after a brief pause and as some kind of afterthought, the interviewee foregrounds her professional identity again. She does this by using a direct quote to voice her own response to these preconceived notions. Instead of going into these membership features further, she simply counters the former ethnic - and limited ethnogendered - categorization by a professional categorization (journalist, line 326). Regarding gender and ethnicity, this categorization is not only neutral but it is also associated with certain epistemological skills. By invoking the identity 'journalist', the interviewee gives a fairly factual, but also strong, response to her co-workers' reactions. This is because, as Potter (1996: 133) notes "simply being a member of some category $[\ldots]$ is treated as sufficient to account for, and warrant, their knowledge of a specific domain". Consequently, this category entitlement implicitly overrules claims regarding limited language skills and maybe even poor living conditions evoked by the term 'the ghetto' (cf. line 321). As a closing remark and a counter to the marked character that was attributed to her characteristics as atypical of the foreigner category, the interviewee reverses the roles by asking her autochthonous colleagues which planet they are from ('Van welke planeet komen jullie?', line 326). Not only does this question ironically categorize her co-workers - instead of the interviewee - as marked because of their unworldly behaviour, but it also alludes to the often asked and stereotypical question regarding the interviewee's ethnic in-group, namely where they are from. This question poses a particular dilemma to second (or third) generation immigrants, who were of course born in the country they live in, instead of in their parents' (or grandparents') country of origin. So her ironic question echoes this difficult situation and by mirroring the question in an exaggerated way, she provides a clever counter. As such, she also illustrates her creativity with words and her ability to respond in an assertive way, which can be regarded as a typical characteristic of a journalist. Thus in this way, she implicitly illustrates some features of her professional identity which make 
her ethnic - and gendered - identity irrelevant for the situation. This construction of a gendered and ethnically unmarked - professional identity can be regarded as a general tendency throughout the interview, both in 'neutral' and in challenged interactional contexts.

\subsection{Interview 3}

The final interviewee is the managing partner of a consultancy firm that aims to promote ethnic diversity in the job market. In this interview, the topic of the interviewee's job content is raised almost immediately. After a few brief introductory questions, the interviewer initiates this topic by asking for a brief job description, as we see in line 7 in the fragment below:

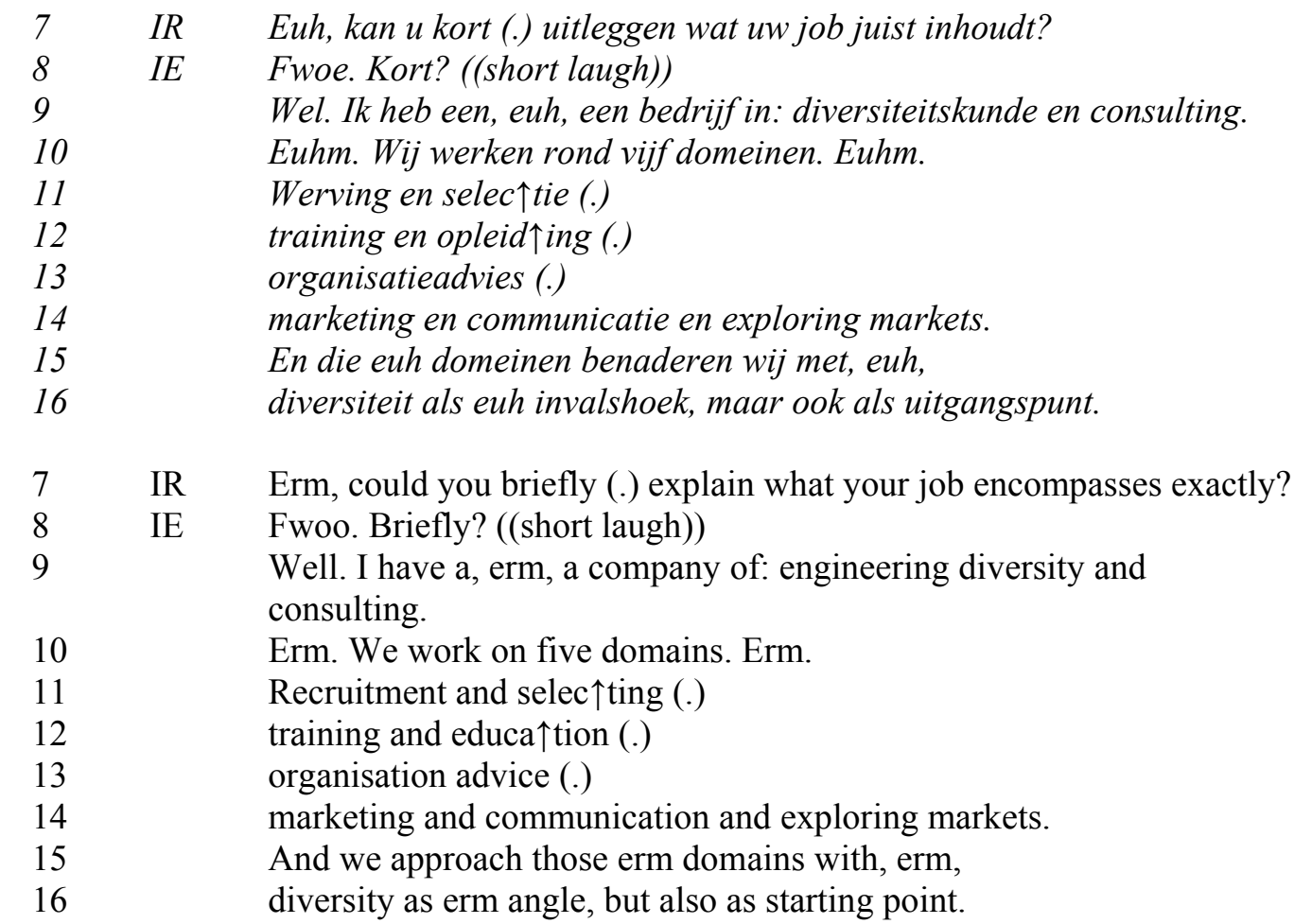

The interviewee starts by ironically (cf. laugh, line 8) problematizing the required short length of her answer ('briefly', line 7 and line 8). As such, she immediately implies her extensive knowledge of this domain which makes it difficult for her to keep her answer brief. Then in her actual answer she uses a personal footing and implicitly outlines her own position at the top of the hierarchy (Ik heb een, euh, een bedrijf, 'I have a, erm, a company', line 9). She then switches to an institutional we-form (line 10 and line 15) and presents the five domains and the major goal of her company. This presentation almost echoes a mission statement. This is because she: Chooses rather formal words; uses English buzz words rather than the more mundane Dutch equivalents (e.g. exploring markets); has a polished pronunciation; uses repeated rising intonation which is accentuated with pauses (lines 11 and 12); and makes precise terminological 
distinctions in the description of the company's approach (e.g. line 16: invalshoek, 'angle' versus uitgangspunt, 'starting point'). By means of this quite abstract description of her company, the interviewee illustrates her ability to use typical managerial talk, and as such she demonstrates her professional identity as managing partner of this company.

Throughout the interview, she consistently constructs this professional identity. Interestingly, as was shown in the company's description in the previous fragment, the interviewee is professionally involved in promoting the position of immigrants on the job market. Since ethnicity is a key element in her professional activities and being of Moroccan descent herself, the interviewee might thus be expected to mix her ethnic and her professional self-categorization. However, this is not the case: The interviewee discusses the job applicants' ethnicity as a problematic factor from a detached point of view and the interviewer explicitly has to shift footing to a personal perspective in order to ask the interviewee about the reactions of customers to her own ethnicity (lines 239240). And even then, the interviewee immediately corrects this ethno-professional categorization:

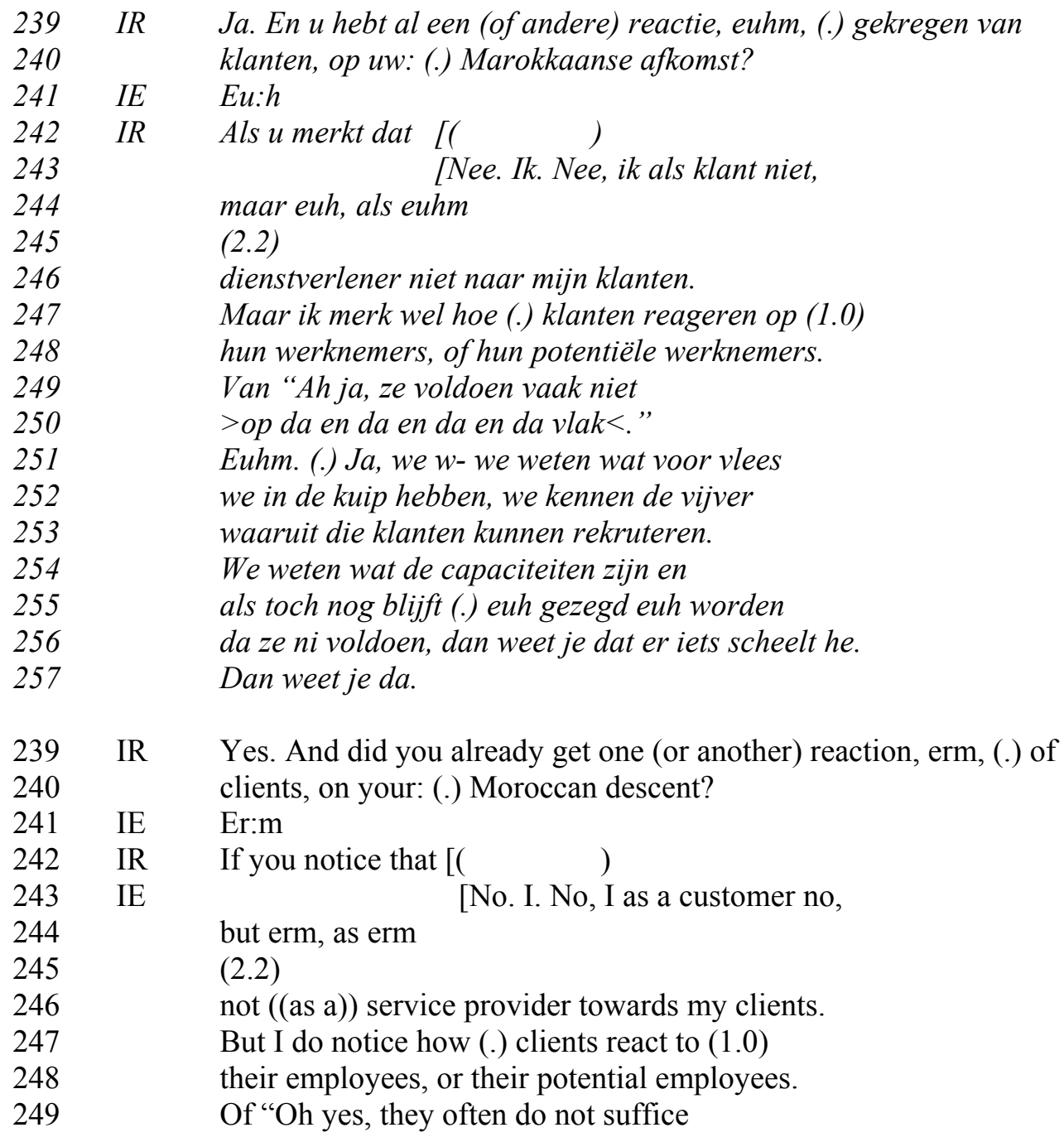


250

251

252

253

254

255

256

257

$>$ in that and that and that and that area $<$."

Erm. (.) Yes, we k- we know who we are

dealing with, we know the pond

from which these clients can recruit.

We know what the capabilities are and

if still it is (.) erm being (.) erm said

that they do not suffice, then you know that there is something wrong hey.

Then you know that.

After an initial pause (line 241) and another prompt by the interviewer (line 242), the interviewee overlaps and immediately responds negatively. She self-categorizes first as a 'customer' (als klant, line 243), but then self-repairs after a few hesitations (line 244) and quite a long pause (line 245). She then categorizes herself on a professional basis as a 'service provider' (dienstverlener, line 246) towards her clients (mijn klanten, 'my clients', line 246). In the following line, she turns the perspective of the question around and gives her view of the issue. As the lexical choice (klanten, 'clients', werknemers, 'employees', lines 247-248) indicates, the interviewee constructs her identity as a professional whose role is limited to that of an uninvolved witness regarding the topic of ethnicity. This witness role is talked into being through the introductory general perception verb merken ('to notice', line 247) which suggests the non-involvement of the interviewee who is a mere observer. Furthermore, she also inserts a direct quote which voices her clients' negative reactions to the allochthonous employees they might hire. Using a direct quote puts the interviewee in the role of mere animator (cf. Goffman 1979) and adds "verisimilitude to the narrated event" (Moita-Lopes 2006: 301). As a response to this direct quote, the interviewee shifts footing to an institutional perspective again (cf. institutional we-forms in lines 251, 252 and 254) and stresses the company's extensive knowledge of the recruitment market. This is shown by the parallel formulation wij weten (lines 251 and 254) and wij kennen (line252) (both translated as 'we know'). So instead of explicitly defending people of foreign descent, she just factually states that her company is well aware of the abilities that are required. Furthermore, she suggests an objective point of view by using impersonal formulations (line 254) and figurative speech (we weten wat voor vlees we in de kuip hebben, "we know who we are dealing with', we kennen de vijver, 'we know the pond', lines 251252). This objective tone is constructed throughout the rest of the fragment: First, by shifting to the passive voice when introducing the clients' negative reactions (lines 255256), and second, by using an impersonal you-form to evaluate these reactions (je in lines 256 and 257), which thus gives her statement a more general scope (cf. discussion above).

Taking these objectifying devices together, the interviewee constructs a factual account which thus avoids the dilemma of stake or self-interest (Edwards and Potter 1992: 158). By immediately shifting the interviewer's ethno-professional categorization to a mere professional self-categorization, she constructs her professional identity as a 'service provider' (dienstverlener, line 246) who is a witness to negative reactions to employees of foreign descent.

Finally, when the interviewer initiates the topic of the work-life balance, which

${ }^{7}$ The figurative aspect is lost in translation, but literally the proverb could be translated as: 'we know what kind of meat we have in the barrel'. 
is introduced in a similar way to the previous interviews, the interviewee - surprisingly - links that to culture. However, she initially invokes her professional identity and speaks from the Western hegemonic perspective.

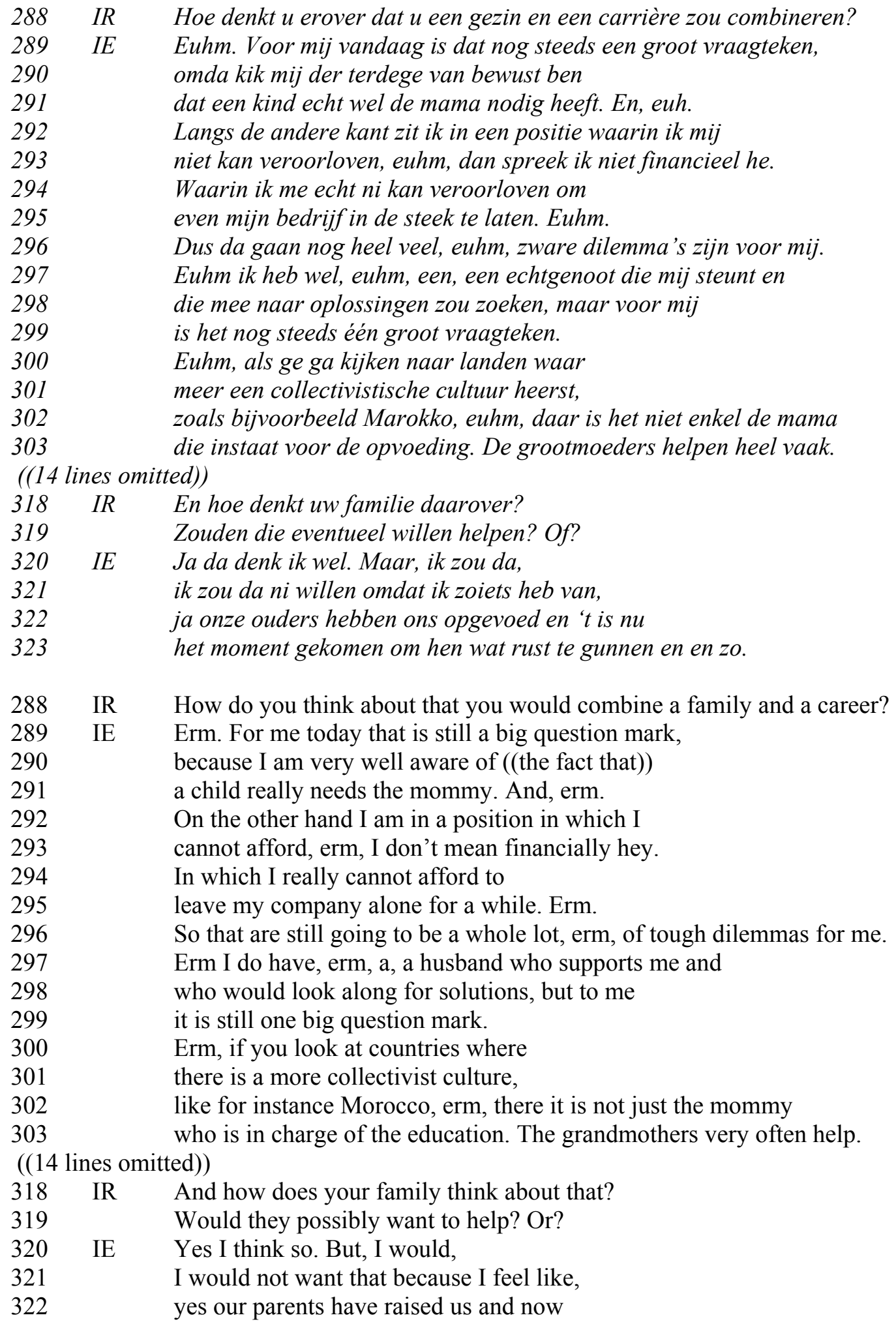


In the first part of her answer (lines 289-296), the interviewee uses a personal footing and voices the issues career women face when trying to combine a family and a career. As such, she foregrounds her professional identity and qualifies it further regarding her hierarchical position at the top of the company. She does this first by using the $1^{\text {st }}$ person possessive pronoun (line 295: mijn bedrijf, 'my company') and second by stressing her indispensability for the company (lines 292-295). Again, the interviewee weighs her words carefully, as the anticipation of the potential misunderstanding of the verb veroorloven ('to afford', lines 293-294) clearly indicates. After closing this initial discussion by means of a summary (line 296), the interviewee introduces her husband. $\mathrm{He}$ is presented as supportive, both explicitly (line 297) and implicitly, as is shown in line 298 by the addition of the adverb mee ('along') to the verb zoeken ('look for'). This turns the Dutch verb into the separable verb meezoeken, which suggests the joint involvement and responsibility of both partners in this hypothetical situation. Still, as the personal framing of her concluding remark demonstrates (voor mij, 'to me', line 298), the interviewee is the protagonist of the 'dilemmas' (line 296). As such, her explanation is in line with dominant Western discourses regarding the difficulties women face when trying to combine a career and family life, even if they have supportive husbands.

In the final, lengthy part of her answer, the interviewee shifts to an impersonal perspective and again constructs her professional identity as an expert. As the generalizing 'you'-form ( $\mathrm{ge}$ ) in the initial sentence already illustrates, the scope of this part of the answer is widened again. Interestingly, the focus is crosscultural and theoretical, as indicated by the reference to Geert Hofstede's cultural dimension of individualism-collectivism (Hofstede 2001) in line 301. As such, the interviewee establishes a shift from a personal narrative to a general, theoretical discussion of collectivist cultures, thus again constructing her identity as a professional and an expert. She illustrates this by means of a fairly long and impersonal discussion of family life in Moroccan culture (which is omitted here). In lines 318-319, the interviewer asks two follow-up questions and shifts to a personal footing, as such attempting to redirect the interviewee's talk back to a narrative of personal experience. The interviewee mirrors this and shifts to a personal footing. On the one hand, she constructs her parents as representatives of Moroccan culture who would follow the 'collectivist' norms, while on the other hand, she constructs her own identity as a Western woman who is oriented to 'individualistic' norms, to quote Hofstede's framework (2001) as introduced by the interviewee.

So this interviewee consistently constructs her identity as a career woman who orients to Western norms and she also performs this role during the interview, in which she constructs the identity of an expert who objectively looks at the matter from a distance. This distancing occurs especially when ethnicity and gender are foregrounded by the interviewer. 


\section{Discussion}

All the interviewees clearly construct their professional identity and they do this in fairly similar ways: They all use institutional we-forms and positive formulations to refer to their current jobs. Furthermore, they all 'perform' their professional identities in the interviews, albeit to differing extents:

- interviewee 1 constructs the hierarchical differences between some of the levels of the Flemish secondary school system, thus demonstrating her orientation to Belgian societal and educational norms (fragment 2);

- by means of a constructed dialogue, interviewee 2 displays her own language skills and this implicitly demonstrates her skill as a journalist (fragment 6);

- interviewee 3 consistently shifts to an impersonal footing and discusses the topics as a professional in a non-involved way (fragments 7,8 and 9).

Especially in the case of interview 3, these 'performances' of professional identity construction sometimes result in shifts in the genre of the interview, which moves on a continuum from a narrative of personal experience to a professional interview in which the interviewee constructs the identity of an expert in the field. This can of course be related to this interviewee's particular profile and her professional involvement in the topic of the interview.

Interestingly, in spite of their diverse profiles, all the interviewees counter the interviewer's ethno-professional categorization with a resolutely professional categorization. This is of course also done in quite different ways:

- Firstly, interviewee 1 and 2 both voice their colleagues' ethnic categorizations ('Moroccan teacher' (interviewee 1) and 'Moroccan journalist' (interviewee 2)). Both respond to them in a critical way. They also counter these ascribed identities by, either implicitly (interview 1) or explicitly (interview 2), stressing their professional identities. Finally, the interviewees' use of direct quotes is quite emblematic of the argumentative nature of these formulations of and responses to such ethno-professional categorizations.

- Secondly, as a response to the interviewer's ethno-professional categorization, interviewee 3 immediately self-categorizes on a purely professional basis. She thus marks the ethnic aspect as irrelevant for her professional identity. Furthermore, she shifts perspective, distances herself and takes on a witness role to discuss this topic, as such suggesting objectivity in her account. So this interviewee counters the marked nature of the ethno-professional categorization by constructing an unmarked professional identity. Paradoxically, on the one hand this identity construction shows no signs of the relevance of ethnicity, while on the other hand, ethnicity is the focus of the interviewee's professional activities.

When the work-life balance and family issues are introduced by the interviewer, the interviewees' responses differ significantly. This is fairly logical given their diverse professional backgrounds (the lower degree of exactingness of interviewee 1's job versus that of interviewees 2 and 3 ) and their different family situations (interviewees 1 and 2 are unmarried, while interviewee 3 is married). However, the interviewees all 
discuss the struggle between gendered and professional identities and thus they demonstrate an orientation towards the Western, hegemonic norm of incompatibility between motherhood and certain highly demanding careers. This is clearly the case in interviews 2 and 3, but interviewee 1 also orients to this hegemonic discourse by stating that she is in 'a sector' which is less demanding for women. Thus these interviewees clearly construct their female identities. By shifting to typical Western issues in their discussion, they at the same time bracket their ethnic identities.

\section{Conclusions}

The analyses of these three interviews demonstrated similar tendencies in negotiating memberships related to profession, gender and ethnicity. All the interviewees treat ethnic boundaries between in-groups and out-groups as either problematic or irrelevant for their professional and gendered identities. However, there are some differences regarding the extent to which ethnicity is recognized as relevant for the interview. Interview 3 is especially interesting in this respect. This is because on the one hand the interviewee distances herself from the topic of ethnicity, while on the other hand she initiates it herself in the discussion of the work-life balance (fragment 9). This demonstrates that ethnicity, although it is part of a person's "transportable identity" (Zimmerman 1998: 90) that can be made relevant "anytime, anywhere" (Zimmerman 1988: 426), is negotiated on a turn-by-turn basis and is constructed in nuanced ways (cf. Schiffrin 1996: 199).

This tendency to make ethnic membership irrelevant in these interviews is actually not surprising. Several reasons can be listed for this. Firstly, the role and characteristics of the interviewer should be taken into account. She is to be regarded as an "active co-teller[s]" (Ochs \& Capps 2001: 23) and the fact that she does not belong to the same ethnic group as the interviewees, may have had an important influence on the stories that are related and the identities that are constructed as an interactional accomplishment. Of course, it is not a matter of which features a person has, but rather which features a person makes relevant in his or her words. And even though the interviewer obviously did not intentionally foreground the ethnic difference between herself and the interviewees, the fact that this issue is raised in the questions makes the interviewer's ethnic identity relevant for the interaction. So, by downplaying their ethnic identities, the interviewees could be considered to be minimizing the difference between themselves and the interviewer and this could be seen as a form of recipient design. Of course, this is a hypothesis and further analyses, for example of interviews conducted by interviewers from the same ethnic background as the interviewees, would be needed to gain a deeper insight into this matter.

Secondly, the fact that the data under study consist of interviews may also have had an influence on the identity constructions. As discussed in the introduction, interviews are characterized by reflexivity and thus the construction of a relatively 'coherent' version of the self (Georgakopoulou 2006: 128) that is also acceptable from a moral point of view (Linde 1993) is expected. One of the hidden points of narratives, according to Linde, is 'to show that the narrator knows what the norms are and agrees with them' (Linde 1993: 123). So the fact that the interviewees orient to societal norms, thus downplaying their ethnic identities which are of course normatively irrelevant at an ideal workplace and in an ideal society, may be related to the interview genre itself. 
Consequently, it is not surprising that the ethnically marked character of the interviewees' professional identities is replaced by an unmarked variant. It is logical that this issue of markedness is something all interviewees refute, since it refers to discrimination, either in a typical, negative sense, but also in a positive sense which would imply that the interviewees' professional feats are not due to their skills, but to policies of reverse discrimination.

Finally, given the findings of Andriessen et al. (2010) that second generation immigrants with a university degree in the Netherlands do not face so much discrimination on the job market, the fact that the interviewees have 'good' jobs is not so marked. Rather, the fact that they succeeded in the preceding step, namely getting a university degree ${ }^{8}$ is more marked in the interaction. Thus in this respect, it may be the unmarked option for the interviewees to refute the relevance of ethnicity in a discussion of their jobs and it may also be viewed as a demonstration of the interviewees' orientation to general societal norms. From this perspective, it would be very interesting to compare these findings with analyses of what happens in contexts that are characterized by a smaller degree of reflexivity, namely interactions in the workplace.

In conclusion, this article demonstrated that people have many potential identities that they can construct and negotiate in their discourse. Since this article only focused on a few selected fragments that particularly dealt with these three categorizations (professional, ethnic and gender), it only covers a tiny aspect of the volatility of alignments, categorizations and identities that occurred in these three interviews. As such, it clearly illustrates the complexity of identities for which no single label - whether second generation immigrant woman, women of allochthonous descent or bicultural women - suffices and it further underlines the non-essentialist nature of identities as they are talked into being, negotiated and resisted in real life.

\section{References}

Andriessen, I., E. Nievers, L. Faulk, and J. Dagevos (2010) Liever Mark dan Mohammed? Onderzoek naar Arbeidsmarktdiscriminatie van Niet-Westerse Migranten via Praktijktests.

Online at: http://www.scp.nl/dsresource?objectid=24186\&type=org. Accessed on 19 May 2010.

Antaki, C. (2002) An Introductory Tutorial in Conversation Analysis. Online at: http://www-staff.lboro.ac.uk/ ssca1/sitemenu.htm. Accessed on 1 December 2009.

Bamberg, M. (2004) Considering counter narratives. In M. Bamberg, and M. Andrews (eds.), Considering Counter Narratives: Narrating, Resisting, Making Sense. Amsterdam: John Benjamins Publishing Company, pp.351-372.

Baynham, M. (2006) Performing self, narrative and community in Moroccan narratives of migration and settlement. In A. De Fina, D. Schiffrin, and M. Bamberg (eds.), Discourse and Identity. Cambridge: Cambridge University Press, pp. 376-397.

Burr, V. (1995) An Introduction to Social Constructionism. London: Routledge.

\footnotetext{
${ }^{8}$ This was also discussed in the interviews but this topic is outside the scope of this article.
} 
Chilton, P. (2004) Analysing Political Discourse, Theory and Practice. London: Routledge.

De Fina, A. (2003) Identity in Narrative, A Study of Immigrant Discourse. Amsterdam/Philadelphia: John Benjamins Publishing Company.

De Fina, A. (2006) Group identity, narrative and self-presentations. In A. De Fina, D. Schiffrin, and M. Bamberg (eds.), Discourse and Identity. Cambridge: Cambridge University Press, pp. 351-375.

De Fina, A. (2009) Narratives in interview - The case of accounts; For an interactional approach to narrative genres. Narrative Inquiry 19.2: 233-258.

De Fina, A. (2011) Researcher and informant roles in narrative interactions: Constructions of belonging and foreign-ness. Language in Society 40: 27-38.

De Fina, A., D. Schiffrin, and M. Bamberg (2006) Introduction. In A. De Fina, D. Schiffrin, and M. Bamberg (eds.), Discourse and Identity. Cambridge: Cambridge University Press, pp. 1-23.

De Standaard (2005) Allochtonen scheiden op z’n Vlaams, De Standaard, 8 October 2005.

De Standaard (2009) Gemeenschapsonderwijs voert algemeen hoofddoekenverbod, De Standaard, 11 September 2009.

De Volkskrant (2010) ChristenUnie Noemt Allochtoon Liever 'Biculturele Burger'. Online at: http://www.volkskrant.nl/binnenland/article1377420.ece/ChristenUnie_noemt_allochtoon_liever_bicultur ele_burger. Accessed on 19 May 2010.

Eggerickx, T., C. Kesteloot, M. Poulain, K. Peleman, T. Roesems, and H. Vandenbroeke (1999) De Allochtone Bevolking in België. Online at:

http://statbel.fgov.be/nl/binaries/11A_nl\%5B1\%5D_tcm325-57837.pdf. Accessed on 12 May 2010.

Edwards, D., and J. Potter (1992) Discursive Psychology. London: Sage.

Georgakopoulou, A. (2006) Thinking big with small stories in narrative and identity analysis. Narrative Inquiry 16.1: 122-130.

Goffman, E. (1979) Footing. Semiotica 25.1/2: 1-29.

Hofstede, G. (2001) Culture's Consequences, Comparing Values, Behaviors, Institutions, and Organizations Across Nations. Thousand Oaks CA: Sage Publications.

Holstein, J.A., and J.F. Gubrium (2003) Active interviewing. In J.A. Holstein, and F. Gubrium (eds.), Postmodern Interviewing. Thousand Oaks, CA: Sage, pp. 67-80.

Johnstone, B. (1996) The Linguistic Individual. New York/Oxford: Oxford University Press.

Labov, W., and J. Waletzky (1966) Narrative analysis: Oral versions of personal experience. In J. Helm (ed.), Essays on the Verbal and Visual Arts. Seattle: University of Washington Press, pp.12-44.

Lesaffer, P. (2011) Hema ontslaat winkelbediende voor hoofddoek. De Standaard, 8 March 2011.

Leudar, I., V. Marsland, and J. Nekvapil (2004) On membership categorization: 'us', 'them' and 'doing violence' in political discourse. Discourse \& Society 15.2-3: 243-266.

Linde, C. (1993) Life Stories, the Creation of Coherence. New York/Oxford: Oxford University Press.

Moita-Lopes, L.P. (2006) On being white, heterosexual and male in a Brazilian school: Multiple positionings in oral narratives. In A. De Fina, D. Schiffrin, and M. Bamberg (eds.), Discourse and Identity. Cambridge: Cambridge University Press, pp.288-313.

Mullany, L.J. (2006) Narrative constructions of gender and professional identities. In T. Omoniyi, and G. White (eds.), The Sociolinguistics of Identity. London: Continuum, pp. 157-172. 
Mullany, L. J. (2009) Gender studies and business discourse. In F. Bargiela-Chiappini (ed.), The Handbook of Business Discourse. Edinburgh: Edinburgh University Press, pp. 213-225.

Ochs, E., and L. Capps (2001) Living narrative, Creating Lives in Everyday Storytelling. Cambridge, MA: Harvard University Press.

OECD [Organisation for Economic Co-operation and Development] (2010) OECD Social, Employment and Migration Working Papers. Online at:

http://www.olis.oecd.org/olis/2009doc.nsf/LinkTo/ NT00006976/\$FILE/JT03273143.PDF. Accessed on 17 May 2010.

Paoletti, I., and G. Cavallaro Johnson (2007) Doing "being ordinary" in an interview narrative with a second generation Italian-Australian woman. In M. Bamberg, A. De Fina, and D. Schiffrin (eds.), Selves and Identities in Narrative and Discourse. Amsterdam: John Benjamins Publishing Company, pp. 89105.

Potter, J. (1996) Representing Reality; Discourse, Rhetoric and Social Construction. London: Sage.

Potter, J., M. Wetherell, and A. Chitty (1991) Quantification rhetoric - cancer on television. Discourse \& Society 2.3: 333-65.

Schiffrin, D. (1996) Narrative as self-portrait: Sociolinguistic constructions of identity. Language in Society 25: 167-203.

Schnurr, S. (2009) Constructing leader identities through teasing at work. Journal of Pragmatics 41: 1125-1138.

Tajfel, H. (1981) Human Groups and Social Categories. Cambridge: Cambridge University Press.

Tannen, D. (1989) Talking Voices, Repetition, Dialogue, and Imagery in Conversational Discourse. Cambridge: Cambridge University Press.

Timor, U., and R. Landau (1998) Discourse characteristics in the sociolect of repentant criminals. Discourse \& Society 9.3: 363-86.

Van De Mieroop, D. (2011) Identity negotiations in narrative accounts about poverty. Discourse \& Society 22.5: 565-591.

Verschelden, W., and P. De Lobel (2006) Geen hoofddoeken aan loket; Coalitie hakt knoop in diversiteitsluik door. De Standaard, 29 November 2006.

Wagner, I., and R. Wodak (2006) Performing success: Identifying strategies of self-presentation in women's biographical narratives. Discourse \& Society 17.3: 385-411.

Zimmerman, D.H. (1988) On conversation: The conversation analytic perspective. In Communication Yearbook 11 (published annually for the International Communication Association). Newbury Park: Sage, pp. 406-432.

Zimmerman, D.H. (1998) Identity, context and interaction. In C. Antaki, and S. Widdicombe (eds.), Identities in Talk. London: Sage, pp. 87-106.

DORIEN VAN DE MIEROOP is an assistant professor of Dutch linguistics at the University of Leuven in Belgium. Her research focuses mainly on identity construction, both in institutional contexts (e.g. speeches, social work interactions, meetings) and in narratives and life stories. She has published a number of articles on this topic (including in Discourse \& Society, Discourse Studies, Journal of 
Pragmatics, Narrative Inquiry, Research on Language and Social Interaction, Pragmatics and Journal of Sociolinguistics).

Address: KU Leuven, Faculty of Arts, Blijde-Inkomststraat 21, P.O. Box 3308, B- 3000 Leuven, Belgium. E-mail: dorien.vandemieroop@arts.kuleuven.be 